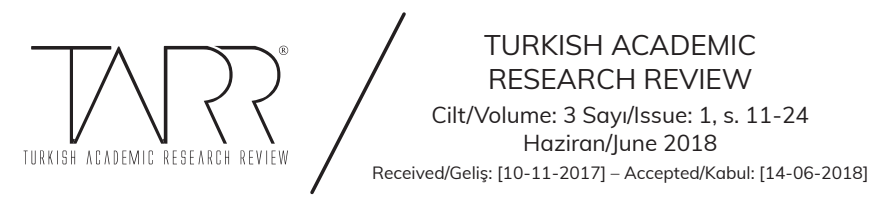

\title{
İslam ve Müzik ${ }^{1^{\star}}$
}

Henry George Farmer

Çev. İbrahim Odabaşı ${ }^{2}$

"Müzik dinlemek yasayı çiğnemektir. Müzik icra etmek dine karşı çıkmaktır. Müzikten zevk almak imanı zedeler ve seni kâfirleștirir."

D’Ohsson, Tableaue genaral de l'Empire Othoman, ii, 188

Mekke'de 571 yılı civarında Arapların ve Arabistan'ın kaderini tümüyle değiştirmeye mukadder olan bir çocuk dünyaya geldi. Bu, "Allah'ın Peygamberi” [Hz.] Muhammed'di. O, 5. yüzylldan beri Mekke'yi idaresinde tutan Kureyş kabilesine mensuptu. O, Mekke'de Kureyş hâkimiyeti kuran ünlü Kusay [bin Kilâb]'ın büyük torunu ve Mekke'nin en önde gelen büyüklerinden biri olan Abdulmuttalib'in torunuydu. $^{3}$ [Hz.] Muhammed yaklaşık kırklı yaşlarında (610), sonradan Kur'ân'ın esasını oluşturan "vahiyleri” almaya başladı.

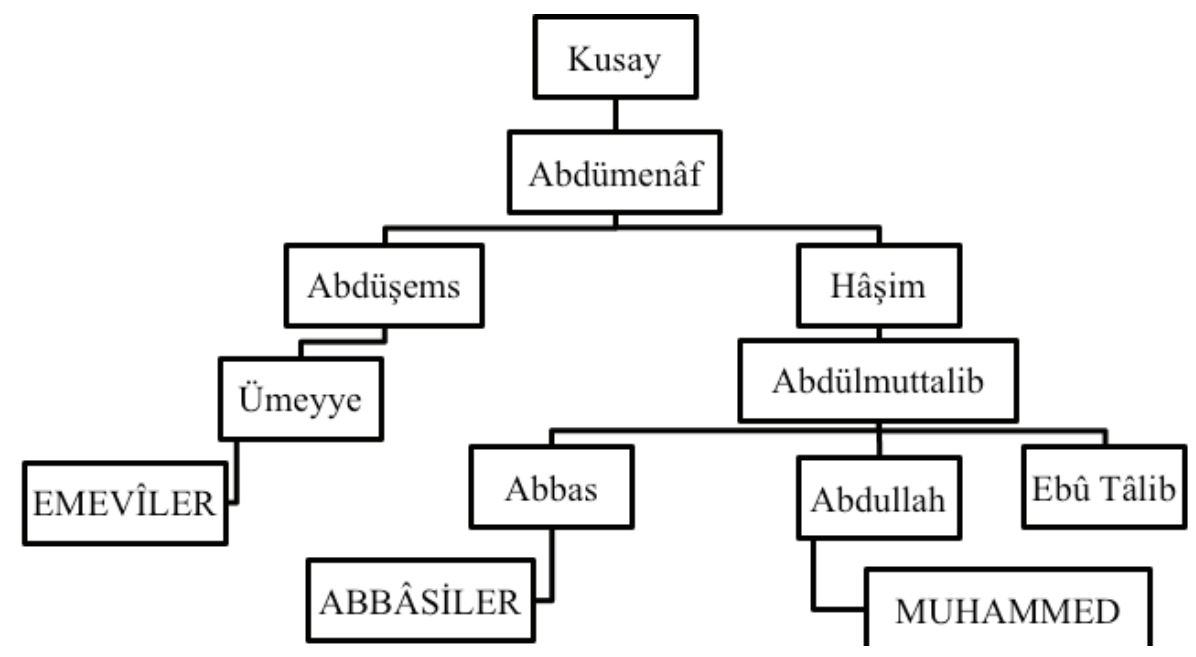

Şekil 1

1 Henry George Farmer, A History of Arabian Music to the XIII th century. London: Luzac\&Co., 1929. "Islam and Music” s. 20-38 bölümünün çevirisidir. Metnin aslında olmayan ve tarafımızdan yapılan ilavelerin tamamı köşeli parantez [ ] içinde verilmiştir. Ayrıca yazar tarafından metinde künyesi verilen bazı ayetler de Elmalılı Hamdi Yazır'ın tercümesi temel alınarak köşeli parantezle dipnotta verilmiștir. Metinde kişi ve yer isimlerinin transliterasyonunda TDV İslâm Ansiklopedisi temel alınmıştır.

2 Akdeniz Üniversitesi İlahiyat Fakültesi Türk Din Musikisi ABD Öğretim Görevlisi; odabasiibrahim@ hotmail.com.

3 Şekil 1 
Ancak Kureyşliler bu "vahiylerin" hiçbirini kabul etmedi ve [Hz.] Muhammed'e güçlü bir biçimde karşı çıktılar. Doğrusu O’nun “vahiyleri” tıpkı şairlerin kullandığı seci ya da kafiyeli düzyazı gibi göründüğü için ilk başta O’nu bir şair (şair-kâhin) veya kâhin (büyücü) olarak düşündüler. Nitekim $O$, gerçekten de bir şair mecnun, yani bir cin tarafından esir alınmış bir kâhin-şair olarak isimlendirilmişti ve sıradan bir müneccim olarak görülüyordu. ${ }^{4}$ Her ne kadar Tebbet suresi (111) tam anlamıyla hicâ [hiciv] veya kâhin laneti iken ve bir kimsenin Felâk (113) ve Nâs (114) surelerini ${ }^{5}$ bir kâhinden beklenenden daha fazlası olmadığ hissine kapılmaksınız zorlukla okuyabilmesine rağmen, [Hz.] Peygamber için yapılan kâhin sıfatı nitelemesi Hâkka suresinde ${ }^{6}(69)$ şiddetle reddedilmiştir.

Zamanla [Hz.]Muhammed'in öğretisi meyvesini verdi ve O'na tâbi olanlar sayıca az olmasına rağmen, onlar arasında Kureyş̧in en nüfuzlu kişilerinden bazıları vard1. Doğrusu O’nun Mekke'deki etkisi öylesine güçlenmişti ki Kureyş’in Ümeyye kolu ona fiilen ambargo uyguladı ve daha sonra Yesrib'e sığınması için zorladı. (622). Bu, "hicret (göç) yılıydı" ve nüfusun önemli bir kısmını oluşturan iki kabileye -Evs ve Hazrec Oğulları- Ensâr (yardımcılar) sıfatı verilmişken, [Hz.] Muhammed sığındığı bu şehre Medine (Şehir) adını verdi. Medine'nin askeri gücünü arkasına alan [Hz.] Muhammed İslam'ın kılıcını inanmayanlara (kâfirlere) karşı kınından çıkarttı.

[Hz.] Muhammed 632 tarihinde vefat etti ama O, Arabistan'da -Bahreyn kadar uzaktaki yerlerde bile- Íslamı Tebliğ vazifesinin başarısına şahit olmuştu. Hicaz, artık Arap yarımadasının cazibe merkezi olmuştu. Yemen'in eski şöhreti, Irak'ın kültürü, Gâssan'ın kudreti, yüzyıl içerisinde Hint kıyılarından Çin hudutlarına, Pireneler'in zirvelerinden Fas'in sahillerine kadar olan alanda tüm insanların zihninde yer eden Hicaz'ın yeni ruhu karşısında hiçbir şeydi.

\section{I}

İslam'da en kafa karıştırıcı meselelerden biri İslam'ın müziğe karşı tutumudur ve yüzyıllardır fakihler, müzik dinlemenin (semânın) caiz olup olmadığı yönünde tartışmaya devam etmektedirler. Kur'ân'da müzik hakkında doğrudan kınayıcı bir kelime bulunmuyorken ve hepsinin ötesinde müziğin, Arapların sosyal hayatının vazgeçilmez bir parçası olması gerçeğine rağmen bu sorunun nasıl ortaya çıktığını kavramak kolay değildir. O halde müzik karşıtı olan bu "hüküm-yetki" nereden

4 Hirschfeld, New Researches into the Composition and Exegesis of the Qoran, 10.

5 Bu surelerin ikisi [Felâk ve Nâs] büyüye ve cinlere karşı bir "tılsım-muska"dır. Bu amaçla, bugün bile bu sureler muskalara yazılmaktadır. Bu surelerle, eski Babil-Asur aşipu muska veya tılsımları arasında çok az fark vardır.

[“Mezopotamya'da tedavi yapan üç rahip grubu vardır. Bârû kâhinler sınıfıdır, bârû’ların görevi hastalıkla ilgili tahminde/öngörüde bulunmak ve teşhis etmektir. Bu sınıfın tek faaliyetleri hastalıkla ilgilenmek değil aynı zamanda kehanette bulunmaktır. Diğer bir sınıf ise Aşipu adını taşıyan büyücü, efsuncu ya da üfürükçü diye tanımlanan gruptur. Bir tür şaman veya efsuncu olan aşipu, hastayı muayene eder ve hastalığa neden olan tanrı veya ruhu belirlerdi. Ardından hastaya, ilgili tanrının gönlünü almak için hediyeler sunmasını isterdi. Aşipu, bazen hastaya nazarlık veya muska takardı”] Bk. Tunalı, Jülide. "Mezopotamya'da Tip ve Uygulanışı,” http://www.academia.edu/31666031/MEZOPOTAMYADA_TIP_VE_UYGULANI\%C5\%9EI (Erişim tarihi 06.03.2018)

6 ["Ve o bir şair sözü değildir. Siz pek az düşünüyorsunuz. Ve bir kâhinin de sözü değildir. Ne kadar az tezekkür ediyorsunuz." Hakkâ, 41-42].

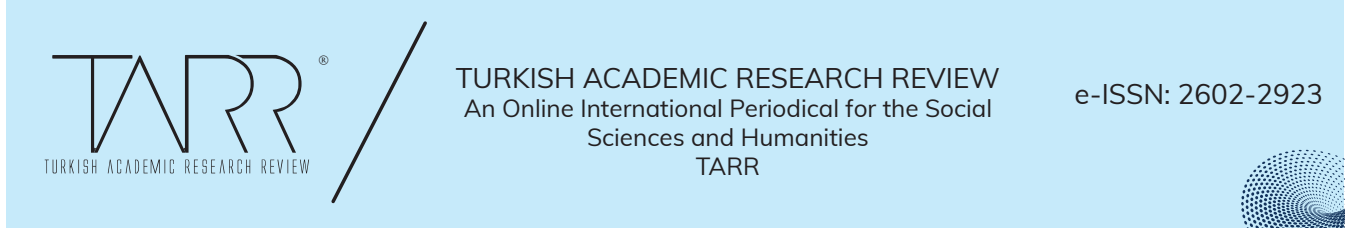


gelmektedir? "Şarap, kadın ve teganni”nin kınanması Sâmi halkı yeni bir şey değildi çünkü Museviler ve Finikelilerde de bu gibi şeylere açıktan karşı gelen püritenler ${ }^{7}$ vardı. ${ }^{8}$ Pagan Araplarında benzer bir düşüncenin yayıldığı görülür ve kâfir şair Ümeyye b. Ebü's Salt, müziğe karşı tek bir kelime bile ağzına almamasına rağmen, bazı konularda oldukça püritendi.

Oryantalistler “müzik dinlemenin” İslami tenkidinin kökeni konusunda ayrılırlar. Bir grup bu tenkidi doğrudan [Hz.] Peygamber'in kendisine dayandırırken, diğerleri Abbasi devri teologlarının müziğe ve müzisyenlere verilen gereğinden fazla ilgiyi kıskanarak uydurmuş olduğunu öne sürer. İlk bakıșta Kur'ân ve Hadis'e başvurularak bu sorunun cevabına ulaşmak kolay bir mesele gibi görülebilir. Fakat Kur'ân, yorumcunun hususi bakış açısına göre yorumlanırken, Hadis, her iki tarafı da destekleyen kesin yargıları içermektedir.

Müfessirler tarafından, "O, yaratmada dilediği kadar artırır. Gerçekten Allah, her şeye gücü yetendir." (Fâtır, 1) ayetindeki ['Ziyâde'den murad'ın] "Güzel Ses" olduğu iddia edilir. ${ }^{9}$ Yine onlar (Lokman, 18), "[Yürüyüşünde tabii ol, sesini alçalt.] çünkü seslerin en çirkini elbette eşeklerin sesidir." ayetindeki çirkin sesin mefhum-1 muhalifinin “Güzel ses” olduğunu söylerler. ${ }^{10}$ Ayrıca "De ki: Allah'ın kulları için çıkardığı ziynetleri ve tertemiz rızıkları kim haram kılmış?” (A'râf, 30) ${ }^{11}$ ayetinde, çok net bir ifadeyle belirtildiği için, şarkı söylemenin caiz olduğu iddia edilir. Diğer yandan buna itiraz edenler, şairlerin kınandığı Lokman Sûresinin 5.-6. ve [7.] -"Ve insanlardan bir kısmı boş sözleri satın alırlar, ilimleri olmaksızın Allah'ın yolundan saptırmak için. Ve onu eğlence (alay konusu) edinirler. İşte onlar için muhin (aşağılayıcı) bir azap vardır."- ayetlerini delil göstererek şarkıda şiir kullanıldığı için şarkı söylemenin "caiz olmadığını", öne sürerler. Bu lanetleme doğrudan -başlangiçta, Peygamber Muhammed'in getirdiği "Vahiyler"den çok daha kolay dinlenilen- Nadr bin Haris'in Pagan şark1 ve hikâyelerine karşıdır. Gerçekten de ilk Müslümanlardan birkaçı, "Boş söz" [lehvel hadis] olarak kastedilen şeyin "şarkı söyleme" olduğunu düşünüyordu ve Ebu Abdurrahman b. Mes'ud (ö.653), İbrahim b. Yezîd en-Nehâi (ö.715) ve Ebu Saîd el-Hasan el-Basrî (ö.728) bunlar arasındaydı. Ayrıca yine Şuara Sûresi 22426 'da -"Şairler (e gelince), onlara da sapıklar uyar. Görmüyor musun, bunlar her vadide şaşkın şaşkın dolaşırlar. [Hem de yapmayacakları şeyleri söylerler.]"- şairlerin kınandığını görüyoruz. Ancak bu da muhtemelen şiire karşı yöneltilen bir şey değildi. [Hz.] Peygamber'in nazarında bu, pagan düşüncelerin vücut bulmuş hali olan ve dahası kendine karşı hiciv ve hakaretler yağdıran şairlere karşıydı. ${ }^{12}$

7 ["16. yüzyılda meydana gelen İngiliz Reformu esnasında, İngiltere Anglikan Kilisesi içinde oluşan bir reform hareketi”.] Bk. Şahin, Mehmet. “İngiliz Püritenizmi.” Necmettin Erbakan Üniversitesi İlahiyat Fakültesi Dergisi 15.15 (2003).

8 İsaya, v, 12 Amos, vi xxiii, 15, 16. Jesus ben Sirach diyor ki: "şarkıcı bir kadınla arkadaşlık yapmayın”

9 Bu görüş Şihab Zuhrîye aittir. Krş. Beydâvî, ii 148.

10 İkdü'l-ferîd, iii, 177. Gazzâli a.g.e. 209.

11 Yazar, metnin orijinalinde ayet numarasını sehven '30' olarak belirtmiş doğrusu '32'olacaktır.

12 [Hz.] Peygamber, düşmanlarını kınaması için Hasan b. Sabit’i resmi şair olarak görevlendirmişti. O, Hasan b. Sabit'e şöyle der; "Onlara karşı hicivler yaz" "Çünkü Allah’a yemin olsun ki senin şiirlerin şafağın karanlığında okların düşmesinden daha etkilidir.” İkdü’-ferîd, iii, 178

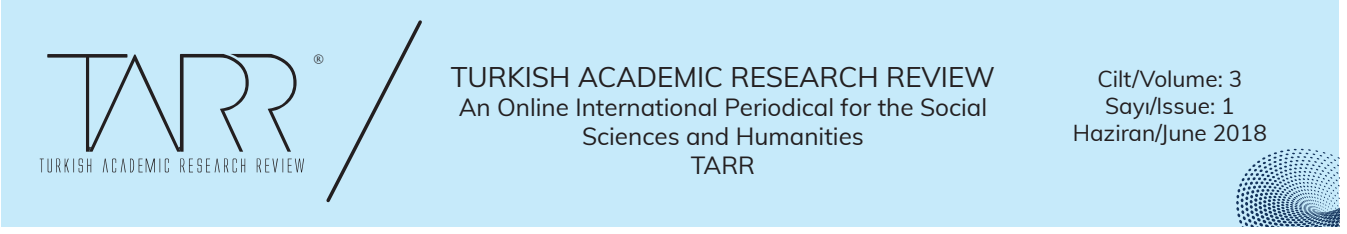


Nadr b. Hâris, Ka’b b. Züheyr ve Nadr b. Eşref vakasından bildiğimiz üzere [Hz.] Muhammed'in şairlerden ve ozanlardan korktuğu ve onların öldürülmesi ve itibarlarının sarsılmasında muvaffak olmak için hiçbir engel tanımadığı konusunda pek az şüphe olabilir. Eski dinin tadında olan her şey, [Hz.] Muhammed tarafindan tahkir ediliyordu. Enfâl Sûresinin $35 .{ }^{13}$ ayetinde 1 slık çalan ve alkışlayanların nasıl alaycı bir üslupta ifade edildiği yazar. ${ }^{14}$ Tüm bunları hesaba katarsak, yine de Kur 'ân' da müziği hor görenler için, müziği ayıplayacak sahih bir temel yoktur. Böylelikle Fakihler Kur'ân'dan sonra gelen "Hüküm” kaynağına dönmek mecburiyetinde kaldılar- yani Hadis.

Hadis, kısmen vahiy kaynaklı ve kanun gücüne erişmiş [Hz.] Muhammed'den rivayet edilen vakıa veya bir söze verilen addır ${ }^{15}$ ve Kur'ân'dan sonra ikinci önemli kaynak olarak görülür. Hangi Hadis'in üstü kapalı kabul edileceği, hangisinin kısmen doğru olduğu ve hangisinin tamamiyla reddedileceği fakihlerin hazırladıkları kurallara göre belirlenir ki bu konuyu burada ele almamız mümkün değil. Şu kadarını söylemek yeterli olacaktır ki Kur'ân'a muhalif olan hiçbir Hadis kabul edilemez. "Müzik dinleme” meselesiyle alakalı çok sayıda "hadis" vardır. Öncelikle müzik "haram"dır görüşünde olanları inceleyebiliriz.

[Hz.] Peygamber'in eşi [Hz.] Âişe, [Hz.] Muhammed'in söylediği bir hadisi naklediyor: "Şüphesiz ki Allah, şarkıcı kızları (kayneleri), onların satılmasını, onlardan elde edilen kazancı ve teganni öğrenmelerini haram kıldı." Gazzâlî, bu Hadis'in yalnızca taverna'daki ${ }^{16}$ kayneler için geçerli olduğunu söyler. ${ }^{17}$ Câbir b. Abdullah, [Hz.] Peygamber adına bir hadis imal ediyor ${ }^{18}$ : "İblis (Şeytan) ilk ağıt yakan ve ilk şarkı söyleyendi." Başka bir Hadis'i de Ebu Umâme tekrarlar: "Her kim tegannide sesini yükseltirse, Allah onun omuzlarına iki şeytan gönderir ve o susana kadar şeytanlar onun göğsünü topuklarıyla döverler." ${ }^{19}$ Ayrıca, "Suyun ekini büyüttüğü gibi Müzik ve teganni, kalpte münafıklığın oluşmasına sebep olur"20 mezkûr hadisin [Hz.] Muhammed tarafından söylediğine inanılırken, bazıları bu hadisin kökenini İbn Mes'ud'a dayandırır. ${ }^{21}$

Tizmizi'nin Sahih [Sünen]'inde (v. 892) -bu hadisin doğruluğu sorgulanmasına rağmen ${ }^{22}$ - [Hz.] Peygamberin şarkıyı ve kayneleri lanetlediği söylenir. ${ }^{23}$ Diğer bir hadiste ise kayneler ve çalgı aletleri (mi’zef-telli çalgılar) kıyamet alameti olarak sayılır, zikredilir. ${ }^{24}$. Müzik aletleri, şeytanın insanları baştan çıkarmak için

13 Onların, Kâ’be'nin yanında duaları 1slık çalıp el çırpmaktan ibarettir. Öyle ise (ey müşrikler) inkâr etmekte olduğunuzdan dolayı tadın azabı.] (Ç.N)

14 Islığın, Araplar tarafından hala şeytanın bir telkini olarak düşünmelerinin nedeni budur.

15 Nicholson, Literary History of the Arabs, 144.

16 İçki meclislerinde erkeklere şarkı söyleyen kadınlar. (Ç.N)

17 Gazzâlî, İhyâu 'Ulûmi'd-Din, J.R.A.S. (1901), s. 217.244-5

18 [Gazzâlî, bu hadisin sahih olmadığını yazmıștır.] (Ç.N) Bk. Gazâli, Ebû Hâmid Muhammed. "İhyâu 'Ulûmi'd-Din, çev." Ahmed Serdaroğlu (İstanbul: Bedir Yay. (1975) (1975).

19 Gazzâlî, İhyâu 'Ulûmi'd-Din, s.246

20 Mişkatü'l-Mesabih, ii, 425

21 Gazzâlî, İhyâu 'Ulûmi'd-Din, s.248

22 Lammens, Melanges de la FaculttOrientate, (Beyrut), iii, 233.

23 Al-Tirmidhi, Al-Sahih. 2 vols. Cairo, 1875. 241

24 Tirmizî, ii, 33

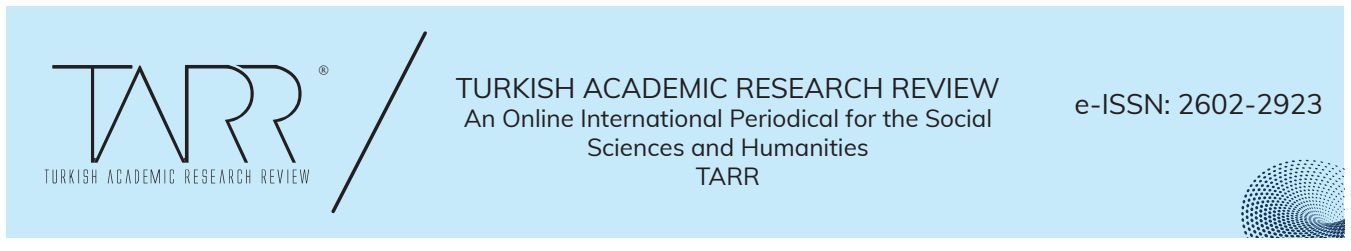


kullandığı, en güçlü silah olarak zikredilir. Bir müzik aleti, şeytana tapmak için insanları çağırmaya hizmet eden şeytanın müezzin'idir. ${ }^{25}$

Fakihler, Peygamberin ashabı ve diğer tanınmıș İslam âlimlerin şahadetlerini "müzik dinlemeye” karşı delil olarak getirirler. Abdullah b. Ömer'in şarkı söyleyen bir hacıyı duyduğunda onu azarladığı ve "Senden Allah'ın ismini duymuyorum" dediği rivayet edilir. Aynı şekilde çalınan bir mizmar'ı işitince durdu ve kulaklarını tıkadı - “Allah'ın elçisinin de böyle yaptığını gördüm” dedi. ${ }^{26}$ [Hz.] Osman için şarkı söylemek yalan söylemek kadar kötüydü ve dedi ki "Şarkı söylemedim ve yalan söylemedim”. ${ }^{27}$ Başka muhalifler, [Hz.] Peygamber’in, -Hasan b. Sabit'in şark1 söylemeyi yasakladığı cariyesi- Şirin'i azarlamasını, [Hz.] Ömer'in şarkı dinleyen sahabiyi kırbaçla cezalandırmasını, [Hz.] Ali'nin, kayneleri yanında bulunduran Muâviye'nin hatalı olduğunu düşünmesini ve onun [Hz.] Hasan'ın şarkı söyleyen Habeşli kadınlara bakmasına izin vermemesini aktarırlar. ${ }^{28}$

"Müzik dinleme"nin lehindeki hadisler, aleyhindeki hadisler kadar sayıca fazla olmasa da daha kuvvetlidir [sahihtir]. Aşağıda, [Hz.] Muhammed'e atfedilen iki hadis vardır: "Allah güzel sesli olmayan bir peygamber göndermedi" ve "Allah, güzel sesle Kur'ân okuyan bir adamı, ustalıkla şarkı söylen bir kayneden daha dikkatli dinler." ${ }^{29}$ Enes b. Malik (ö.715)'ten naklediliyor ki: [Hz.] Peygamber, seyahat esnasında Enes b. Malik'e hudâ (kervan şarkısı) söyletiyordu. Encüsse kadınlar için ve Berâ b. Malik erkekler için şarkı söylüyordu. ${ }^{30}$ Gazzâlî kaydeder ki: Hudâ, Allah'ın elçisi ve sahabeler zamanında, terk edilen bir Arap geleneği olmadı. Ki Hudâ, ölçülü melodiler (Elhânü'l-mevzun) ve uyumlu seslerle (Savtü't-tayyibe) okunan şiirden başka bir şey değildir. ${ }^{31}$

Daha önceki Hadis'lerde kaynelerin yasaklanmasina gelince, [Hz.] Peygamberin onları "helal" gördüğüne dair çok kuvvetli deliller vardır. Öncelikle, [Hz.] Peygamber'in, Hasan b. Sabit'in ikamet ettiği yerden geçerken kaynelerin sesini işitmesi ile ilgili bir hadis vardır. "Şair, şarkı söylemenin günah olup olmadığını sordu. [Hz.] Peygamber yanıtladı: Kesinlikle değildir!”32

Bu soruyla ilgili [Hz.] Aişe’den iki rivayet vardır. İlki “[Hz.] Ebubekir Mina gününde [Hz.] Aişe'nin yanına geldi ve onunla birlikte iki kız def çalıyor ve ritim tutuyorlardı bu sırada da [Hz.] Peygamber ridâsıyla başını örtmüştü. [Hz.] Ebubekir onları azarladı ancak [Hz.] Peygamber örtüsünü kaldırarak ona 'Bırak onları Ebubekir, bayram günleridir.' ${ }^{33}$ dedi. İkincisi şöyle devam eder: "Benimle birlikte iki kız Buas günü şarkısı söylüyorken (ğına), Allah'ın elçisi bana geldi ve yatağa yanı üzerine uzandı ve yüzünü de arkaya çevirdi. Sonra [Hz.] Ebubekir geldi ve

25 Lane, Arabian Nights, i, 200.

26 Gazzâlî, İhyâu 'Ulûmi'd-Din s.248. İbn Hallikân, Biog. Diet., iii, 521

27 Lisânü'l-Arab

28 Keşfü'l Mahcûb, 411

29 Gazzâlî, İhyâu 'Ulûmi'd-Din, s.209

30 Gazzâlî, İhyâu 'Ulûmi'd-Din, s.209

31 Gazzâlî, İhyâu 'Ulûmi'd-Din, s.207

32 Üsdü'l-ğâbe, v. 496

33 Gazzâlî, İhyâu 'Ulûmi'd-Din, s.24-5.

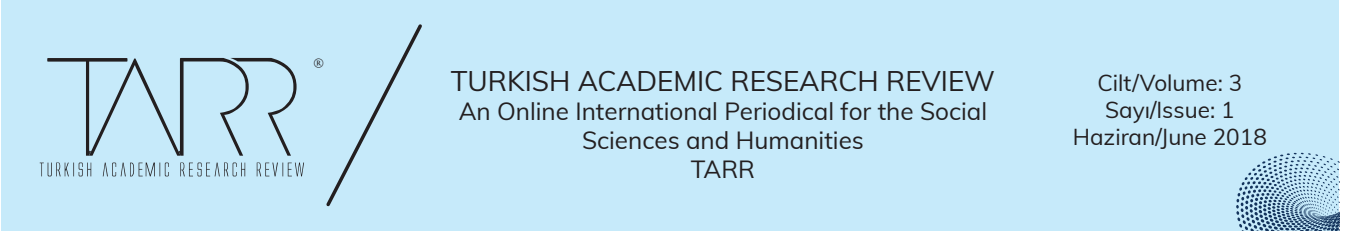


'Allah'ın elçisinin huzurunda Şeytanın düdüğü (mizmarü'l şeytan) ha!' diyerek beni (Hz. Aişe) azarladı ama Allah'ın elçisi ona dönerek: 'onları bırak!’34 dedi.

[Hz.] Aişe'den diğer bir rivayet ise aşağıdaki gibidir: “[Hz.] Ömer içeri girmek için izin istediğinde, bir köle kız benim evimde şarkı söylüyordu. Köle kız onun ayak sesini duyar duymaz kaçtı. [Hz.] Ömer içeri girdi ve [Hz.] Peygamber gülümsedi. 'Ey Allah'ın elçisi dedi [Hz.] Ömer, seni böyle güldüren şey nedir'. [Hz.] Peygamber yanıtladı: 'Köle bir kız burada şarkı söylüyordu lakin senin ayak sesini duyunca kaçtı.' [Hz.] Ömer, 'Allah'ın elçisinin dinlediği şeyi duyuncaya kadar buradan ayrılmayacağım’ dedi. Böylece [Hz.] Peygamber kızı geri çağırdı, kız tekrar şarkı söylemeye başladı ve [Hz.] Peygamber onu dinledi." ${ }^{5}$

Başka bir vesileyle, kayneler şarkı söylüyorlarken [Hz.] Peygamber Rubeyy bint Muavvı'ın evine girdi, onlardan biri [Hz.] Peygamber'in içeri girdiğini fark ederek "Yarının ne olacağını bilen bir Peygamber aramızdadır." demesi üzerine [Hz.] Peygamber: "Bu sözü bırak da neyi söylüyordun ise onu söyle” buyurdu. ${ }^{36}$

Biz ayrıca [Hz.] Peygamber’in teşrifi sırasında, kadının selamlama cümlesini, dama çıkarak, def eşliğinde nağme (lahn) ile (inşâd) [resitatif] şeklinde söylediğini de okuyabiliriz. ${ }^{37}$ Son olarak, [Hz.] Aişe'nin Ensâr'dan birine gelin götürmesi hadisesi vardır. [Hz.] Aişe geri döndüğünde [Hz.] Muhammed ona sordu "-K1z1 kocasina götürdün mü ?” [Hz.] Aişe, "-Evet” dedi. [Hz.] Peygamber daha sonra “-Şarkı söyleyebilen birini göndermedin mi?” diye sordu. [Hz.] Aişe“-Hayır." dedi. Sonra [Hz.] Peygamber “-Şüphesiz biliyorsun ki, Ensâr, gazelden (aşk şarkısı) keyif alan kimselerdir." ${ }^{38}$

Bazı fakihler, Kur'ân'ın şiiri ve şairleri kınamasını, doğrudan müziğe karşı olarak görseler de diğerleri şiirin caiz olduğu ve şarkının da şiirden çıktığı için onun da caiz olması gerektiği bakış açısını savundular. İkdü’l ferid'in yazarı diyor ki: "İnsanlar, konu şarkıya (ğına) gelince ihtilafa düşerler.” Hicaz'daki insanların çoğu ğınaya izin verir ancak Irak'takilerin çoğu ğınadan hoşlanmaz. Bunu caiz olarak görenlerin kanıtlarının bir kısmı, ğınanın kökenini, [Hz.] Peygamber'in emrettiği şiire dayandırır. O şiire teşvik etti ve ashabına tavsiyede bulundu çünkü inanmayanlara (kâfirlere) karşı şiiri yardımcı bir unsur olarak gördü. ${ }^{39}$ [Hz.] Aişe de şöyle söylemişti: "Çocuklarınızın dillerini tatlandıracak şiirler öğretiniz." ${ }^{4}$ Ayrıca, [Hz.] Muhammed ashabından bazıları ile seyahatleri esnasında ashabından birinden, Umeyye'nin şiirinin okumasını istediği kaydedilir. Onun için yüz mısra1 okundu ve bittiğinde [Hz.] Peygamber "Aferin!” dedi. Ayrıca rivayet edilir ki “Onlar şiirde hicvedildiğinde bu onları usandırır." "Şiir iyidir ve biz güzel bir nağmede (lahn) herhangi bir zarar görmeyiz” dedi. ${ }^{41}$

\footnotetext{
34 Gazzâlî, İhyâu 'Ulûmi'd-Din, s.26.

35 Keş̧üll Mahcûb, 401

36 Gazzâlî, İhyâu 'Ulûmi'd-Din, s.743.

37 Gazzâlî, İhyâu 'Ulûmi'd-Din, s.224.

38 İkdü'l-ferîd, iii, 178.

39 Gazzâlî, İhyâu 'Ulûmi'd-Din, s.224

40 Gazzâlî, İhyâu 'Ulûmi'd-Din, s. 224

41 A.g.e. Şiir açıkça söyleniyordu.
}

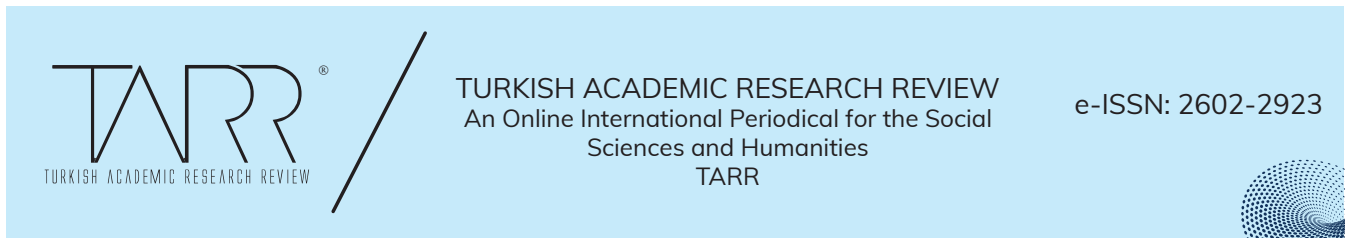


Başka bir vesile ile [Hz.] Peygamber bir köle kızın önünden geçerken, kız yüksek sesle şarkı söylemeye başladı "Eğer neşeliysem (Eyvahlar olsun!) üzerimde herhangi bir suç var mıdır?” [Hz.] Peygamber ona cevap verdi: "Allah'ın izniyle suç olmayacak." ${ }^{42}$ Rüyasında [Hz.] Peygamberi gördüğünü söyleyen Dîneverînin (ö.895) büyük önem atfedilen rivayeti şöyledir: Dîneverî [Hz.] Peygambere, müziği ve şarkı söylemeyi suçlayıp suçlamadığı sordum. [Hz.] Peygamber cevaben "Onda suçlanacak hiçbir şey yok ama söyle onlara [müzik ve şarkı söylemek isteyenlere] müziğe Kur'ân ile başlasınlar ve yine Kur'ân ile bitirsinler.'dedi. ${ }^{43}$

Büyük Kitâbü'l-egâni'de (10. Yüzyıl) geçen rivayetlerden biri, İslam'ın doğuşunda, özellikle müziği yasaklayan bir şey olmadığını göstermiştir. Kureyşliler, ünlü şair-ozan A'şa, Meymûn b. Kays'in [Hz.] Muhammed'le görüşmek üzere yolda olduğunu duymuş ve onun yolunu kesip durdurmaya karar vermişlerdi. [Hz.] Peygamber'in, Kays'ın aşırı bağımlı olduğu birçok şeyi yasaklamış olduğuna dikkat çekerek, onu bu düşüncesinden vazgeçirmeye çabaladılar. "Nedir bunlar ?" diye sordu şair. Kureyş büyüklerinden Ebû Süfyan, "Onlar: zina, kumar, faiz ve şarap” diye yanıtladı. Kays'ın sanatla ilgilendiği göz önüne alındığında, müzik de yasaklanan şeyler arasında olsaydı mutlaka onun da bahsi geçerdi. ${ }^{44}$

Hadisler [Hz.] Muhammed'in enstrümantal müziğe müsaade ettiğini israrla doğruluyor. ${ }^{45} \mathrm{O}$, bir gün şöyle söylemişti: “ Evliliği ilan ediniz ve girbâl (bendir) çalınız. ${ }^{46}$ [Hz.] Hatice ile kendi evlikleri ve aynı şekilde kızı [Hz.] Fatma'nın evliliği de müzik ile kutlanıldı. ${ }^{47}$ Meşhur rivayetler, [Hz.] Peygamberin ashabı ve destekçileri arasındaki birçok müzisyenden bahseder. ${ }^{48}$

Bu "rivayet” ve "şahadet”ler bilmecesinden yola çıkarak İslam,“müzik dinlemek” konusunda bir hüküm ortaya koymaya çalıştı. Dört büyük mezhep imamları Hanefî, Mâlikî, Şâfî ve Hanbelî, hem fakihler ve hem de fakih olmayan kimseler tarafından müziğin caiz olduğu yönünde yüzlerce ilmi eser yazılmasına rağmen, açık bir şekilde müziğin caiz olmadığ1 yönünde karar verdiler. Ebu Hanîfe (699767), her ne kadar çalg1 aletlerine cevaz vermiş görünse de ${ }^{49}$ onun "şarkıdan (ğına) hoşlanmadığı ve şarkı dinlemeyi de günah saydığı” söylenir. ${ }^{50}$ Ayrıca Enes bin Mâlik (715-795), şarkı söylemeyi yasakladı ve "Bir adam şarkı söyleyen köle bir kızı aldığında veya bulduğunda, ilk işi onu göndermek olmalıdır." ${ }^{1}$ dedi. İmam Şafiî (767-820) "Şarkı söylemek (ğına) sahteliği andıran ve hoşlanılmayan bir eğlencedir; anlamın ışığına burnunu sokan (hakikate ulaşmayı engelleyen)

42 Gazzâlî, İhyâu 'Ulûmi'd-Din, s. 224

43 Gazzâlî, İhyâu 'Ulûmi'd-Din, s.

44 Eğânî, viii, 85-6

45 [Hz.] Muhammed ve müzik ile ilgili bölümler ayrıca bulunabilir. Bk. İbn Hacer, iii, 20. İbn Sa'd Tabakât, iv(i) 120 .

46 Gazzâlî, İhyâu 'Ulûmi'd-Din, s.207. Lisânü’l Arab, s. "ghirbal”

47 Evliya Çelebi, Travels, i,(ii) 226.

48 Evliya Çelebi, Travels, i,(ii) 226

49 Gazzâlî, İhyâu 'Ulûmi'd-Din, s.202.

50 Hidâye, iii, 558

51 Gazzâlî, İhyâu 'Ulûmi'd-Din, s.201

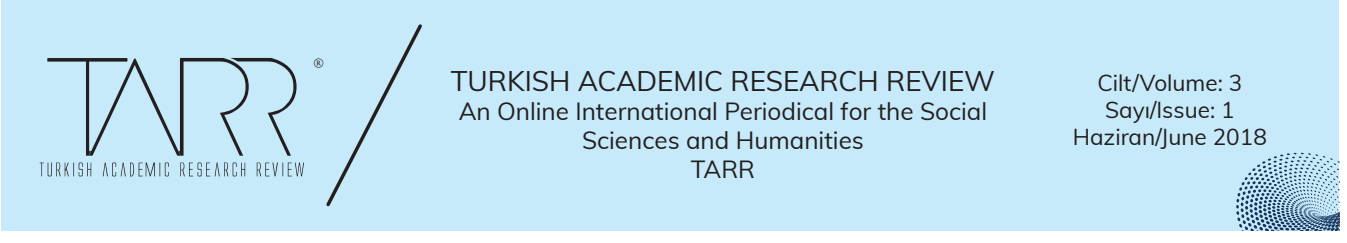


o kimsenin [şahadeti merdûttur] şahadetini reddetmelisin." ${ }^{22}$ dedi. Ahmed b.Hanbel (780-855) müzik (semâ) dinlemekten hoşlanmazd1 ${ }^{53}$ Böylece anlıyoruz ki bizzat dört büyük mezhebin kurucuları, her ne kadar görüssleri bir hayli farklı olsa da müzik (sema) dinlemeye karşıydılar.

Öyle görünüyor ki yukarıda Şâfîi’nin müziği kınamasına karşın, [enstrümantal] müziği kendisi içinde caiz olarak kabul etti. Fakih [Yûnus b. Abdüla'lâ] Şâfii’ye [Medine halkının müziği mübâh saydıklarının hikmetini] sorduğunda: “Hicaz'da müzik ve şarkı söylemenin-âşıkane tasvirler dışında- kerih olduğunu görmedim: Hudâ (kervan şarkısı) ise, bahar otlaklar1 ${ }^{54}$ ve kamp alanlarının nerelerde olduğundan bahseden ve söylenen şiirde sesin güzelleştirilmesiyle oluşur. Ki bunlar mübahtır." ${ }^{55}$. Bu nedenle onun mezhebinde hudâ ve benzeri şeyleri söylemek de dinlemek de caiz olarak kabul edilir. Müzikal enstrümanların eşlik etmediği diğer tüm şarkılar yasaklanır. Ancak eğer ki bu enstrümanlar gayri meşru arzulara meylettirme eğilimindeyse ve yasaklanan enstrümanlar arasındaysa-ud, sanc, Irak neyi, barbat, rebab vb.- cevaz verilmemiştir. Bunlar profesyonel müzisyenler tarafından kullanılan enstrümanlardı ve onların işi salt estetik ve caiz olmayan hazlardı ve onlar kınand1. ${ }^{56}$ Gazzâlî, bu enstrümanlara itirazın sebebini "muhannesler [efemineler] ve içki içen insanlara işaret etmesine" bağlıyor. ${ }^{57}$ Bunun yanı sıra davul, şahin, kadib, gırbal veya def hacılar tarafından kullanıldıkları için "cevaz verilen" enstrümanlard1. ${ }^{58}$

Şafiî hükümlerinden genel çıkarımlara göre, "haram olan” enstrümanların herhangi biri, (belirli şartlarda) kırılabilir veya yok edilebilir. Bu enstrümanları kıran veya yok eden kişinin de herhangi bir yasal yükümlülüğü olmaz. ${ }^{59} \mathrm{Bu}$ durumda öyle görünüyor ki fıkhî sorun, enstrümanların mülkiyet olup olmadığı meselesi etrafında dönüp dolaşmaktadır. Eğer bu enstrümanlar "haram”sa, bir Müslüman'a ait olamaz ve bu nedenle "mülkiyet"i de olamaz. Böylelikle bir Müslüman onları imha edebilirdi. Şafiî mezhebi bu kadarlık yeterlidir.

Hanefî mezhebi bu müzikal enstrümanların “mülkiyet” olduğunu ileri sürüyor ve neticede kazanç sağlayan beceri yasal bir avantajdır. ${ }^{60}$ Enstrümanların haram maksatlı kullanılmış olması, onların "mülkiyet” olduğu gerçeğini değiştirmez. Böylece bu mezhep tarafından verilen hüküm şudur ki; "Eğer bir kişi bir Müslüman'ın def'ini, barbat'ını, tabl'ını, mizmar'ını kırarsa o kimse, bu gibi malların satışı caiz olduğundan sorumlu tutulur." Bazıları, iki mezhep arasındaki farkın yalnızca eğlence için kullanılan araçlara [enstrümanlara] göre değiştiğini söyler. ${ }^{61}$

52 Gazzâlî, İhyâu 'Ulûmi'd-Din, s.201

53 Gazzâlî, İhyâu 'Ulûmi'd-Din, s.201

$54 \mathrm{Bu}$, tek başına kullanıldığında kıt'a olarak adlandırılan kasidenin ilk kısmını (nasib) ifade eder.

55 Gazzâlî, İhyâu 'Ulûmi'd-Din, s.242-3

56 Gazzâlî, İhyâu 'Ulûmi'd-Din, s.214. Nevevî, 515

57 Kuba adı verilen davul, muhannesler tarafından kullanılması nedeniyle kınanmıştı.

58 Gazzâlî, İhyâu 'Ulûmi'd-Din, s.214, 237, 743.

59 Nevevî, 200.

60 Ebu Hanife'nin şarkı söyleyen bir komşusu vardı. O "sesini kaybettiği” için Ebu Hanife onun kefaletini ödeyerek hapisten çıkardı. İkdü’l Ferid, iii, 181

61 Hidâye, iii, 558-9

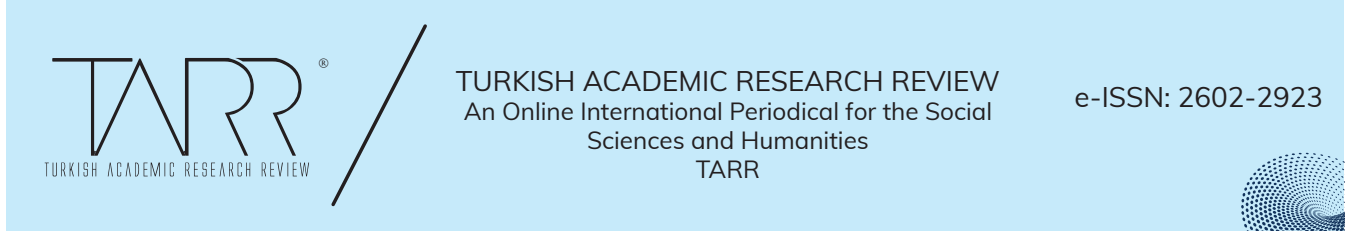


Elin kesilmesi ile cezalandırılan belirli hırsızlık sınıfları vardır. Ancak Şafiî mezhebi şöyle bir iddiada bulunur: "İmameyn'e ${ }^{62}$ göre, çalınan def, tabl, veya mizmar için hırsızın eli kesilmez, çünkü onların düşüncelerine göre, bu nesnelerin mali bir değeri yoktur." Hanefi mezhebi de şunu vurgular: "Ancak, Enstrümanları çalan hırsız onları yok etmek için çaldığını söyleyebilir. ${ }^{63}$ Aynı hüküm tanbur ve diğer telli çalgılar (mezâif) için de uygulanır. ${ }^{64}$

Müzik tedarikçisi [Çalg1 aleti satan] de, fakihlerin ellerini üzerinde hissetti. Harun Reşid (786-809) zamanında, bir müzisyen mahkemelerdeki normal yargıya kabul edilmedi. İmam Şâfî, müzikle iştigal eden bir kişinin şahadetine güvenilemeyeceğini kesin olarak ifade etmiştir. Hidâye'ye ${ }^{65}$ göre "Şarkı söyleyen veya ağıt yakan kadının şahitliği, -[Hz.] Peygamber bu iki ses türünü yasakladığına göre-yasaklanan eylemlerin suçundan dolayı kabul edilebilir değildir." ${ }^{66}$ Ebu İshak eş-Şirazînnin (ö.1083) Tenbih'inde genelde şarkıcılar da bu yasaya dâhil ediliyorlardı. ${ }^{67}$ Hidâye ayrıca şunu açıkça belirtir: “ Ne bir şarkıcıya ne de bir ağıtçıya vasiyet etmek caiz değildir. ${ }^{68}$

Müziğe karşı yapılan tüm bu cezalar ve kısıtlamalar göz önüne alındığında, İslam şemsiyesi altında sanatın gelişmiş ve zenginleşmiş olması bir mucizedir. Gerçek şu ki: teologların ve fakihlerin zorlamalarına rağmen“müzik dinlemeye” ilişkin hükümlerde yasaya uymaktansa daha çok ihlal edilmesine itibar edildi. Bu açıdan günahkârların daima kaçacak bir yolları [mevzuatta açık yakalamak gibi] vardı. İkdü'l -ferîd'deki bir hikâye ile bu çok iyi tasvir edilmiştir. Hicaz'in önde gelen adamlarından biri hacca gidiyordu ve seccadesinin üzerine uzanmış halde şark1 söylüyordu. Yanından geçen erkek akrabalarından biri: "Keşke bir sâlik olarak [hac yolcususun] yaptığın böyle şeyleri duymamı Allah nasip etmeseydi.” diyerek onu ayıpladı. Suçlanan kimse de: "Yeğenim, sen de söylediklerimi dinlemiyor musun? diye cevap verdi." ${ }^{69}$ Hükmün yasaklığı, sadece şarkıcı ve çalgıcıyı değil aynı zamanda onu dinleyeni de kapsar. ${ }^{70}$

Müzik söz konusu olduğunda, İslam gerçekten de Arapların Pagan ülkülerini tamiyla yok etmedi. Her ne kadar "müzik dinleme” (semâ) aleyhindeki suçlama, müziği destekleyecek daha fazla şey olmasına rağmen Abbasi teologları tarafından üretildi argümanını destekleyecek hayli malzeme olsa da, bu ayrışmanın temelinde dolaylı olarak [Hz.] Muhammed'in [uydurma hadislerin] sorumlu olduğu hususunda pek az şüphe vardır. ${ }^{71}$

62 [Ebû Hanife'nin önde gelen iki öğrencisi İmam Muhammed ve İmam Ebû Yusuf].

63 Hidâye, ii, 92.

64 Hidâye, ii, 89.

65 "Hanefilerin klasik fetva kitabıdır." (Ç.N.)

66 Hidâye, ii, 687.

67 Tenbîh, 336.

68 Hidâye, iv, 212.

69 İkdü'l-Ferid, iii, 178

70 D’Ohsson, ii, Gen. i88.

71 Bir Müslüman şöyle dedi: "Dindar insanlara, hadislerde verilen yanlış bilgi kadar, başka hiçbir yerde yanlış bilgi yoktur.” (Noeldeke, Gesch. desQorans, 22). Bununla birlikte bunlar bilinçli üretilen yalanlar değildir. Çünkü [Hz.] Peygamberin şu hadis[ler]ini hatırlamak zorundayız: "İyi her ne şey rivayet edilmişse, onu ben söylemişimdir.” Ve ayrıca, “Benden rivayet edilen her şeyi Allah'ın Kitabına arz ediniz. Ben

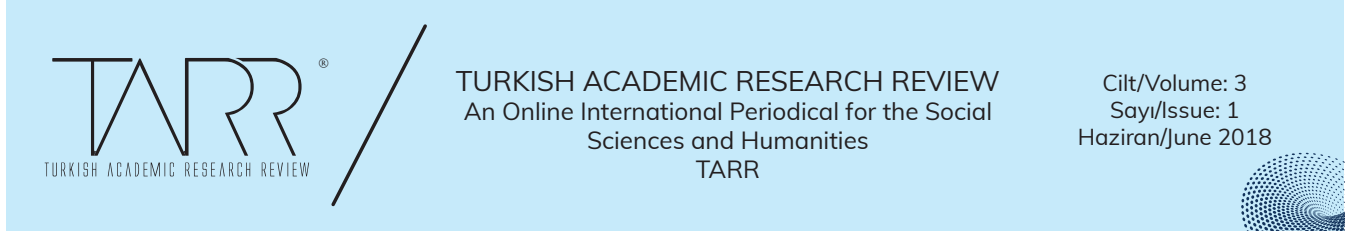


[Hz.] Muhammed'in tutumuna tamamen fizyolojik zeminde açıklık getiren bazı yazarlar vardır. O’ndaki duyular-algılar olağanüstü gelişmiş görünüyordu. O'nun koku alma duyusu ona gerçek bir yüktü. O, dokunma (temas etme) konusunda da aşırı duyarlıydı. Gastronomi mevzuları hemen hemen O'nunla, bir takıntı halini aldı. O'nun sanrıları vardı. Onun kulaklarındaki uğultular başını ağrıtıyordu ve duyduğu kedi, yaban tavşanı ve çan sesleri acı çektirmese de çok rahatsızlık veriyordu. Kervan zillerinin çınlaması bile O’na rahatsızlık verirdi. Böyle olağanüstü bünyede aşırı bir duyuya sahip olmak, fıtrî olarak müziğe karşı isteksizliğinin -en azından onun cazibesi ve güzelliğine duyarsızlı̆̆ının - makul bir sebebi olabilir. Aynı neden onun ritim duygusunun eksikliğine de bağlanabilir. ${ }^{72}$ Bununla birlikte, [Hz.] Muhammed'deki fiziksel ve psikolojik refleksleri abartmak çok kolaydır: lakin gerçekte bu satırlara itiraz eden ve karşı çıkan birçok Hadis vardır. Dr. Hartwig Hirschfeld ortaya koymuştur ki: bu sözde "Ritim duygusu eksikliği", prozodik biçimlerin -sadece bir kâhin veya sihirbaz olarak kabul edilmesin diye[Hz.] Muhammed tarafından göz ardı edilmesi kasti bir teşebbüstü. [Hz.] Muhammed halkın şiirsel duyuru türlerinin genel biçimlerinin taklidinden kaçınmıştı ve bu ona muazzam bir sıkıntı vermişti. Yine de $\mathrm{O}$, ürcûze (recez vezinli) formu olan "mâni”lerden kaçmayı başarsa da, seci'den (kafiyeli düz yazı) kaçamadı. ${ }^{73}$

[Hz.] Muhammed'in müzik konusundaki tutumu belki bu minval üzere açılanabilir. $\mathrm{O}$, paganizm ideallerinin övüldüğü şiirler eşliğinde yapılan müzik türünden kaçınmak zorundaydı. Vahiylerini ulaştırmak için, kendisi "Güzel Sesle” kutsanmamış olabilirdi, fakat $\mathrm{O}$, kesinlikle bunun değerinin farkındaydı. Ebu Manzure'yi "Güzel Ses "inden dolayı tercih ederken Ebu Musa el-Eş'ari'nin okumasını (kıraat) "Davut'un mizmarlarından bir mizmara" benzetti. ${ }^{74}$ [Hz.] Muhammed dinleyicilerinin zihinlerini pagan düşüncelerinden uzak tutacaksa, Kur'ân terennümü, şiirlerin terennüm ediliş tarzından farklı olmalıydı ve böylece meşru bir olgu olarak Kur'ân tilaveti (tağbir) ve tahlîl'in belirlenmiş terennümleri ortaya çıktı. ${ }^{75}$ $\mathrm{Bu}$ terennüm tıpkı müzikteki gibi öğrenilen ya da öğrenilmeden [formal-informal] bir kişi tarafından kavranabilen- bir profesyonel müzisyene ait olan şarkıdan veya ğınâdan farklı bir tarz olan- bir ses modülasyonuydu. ${ }^{76}$ Kur'ân tilavetinin Sicistân'ın valisi Ubeydullah b. Ebubekir (697 yılında atandı) tarafından uygulandığı söyleniyor, fakat daha erken bir dönemde uygulandığı aşikârdır.

Ezan, hicret'in birinci ya da ikinci yılında [Hz.] Peygamberin kendisi tarafından ilan edildi ve Bilal Habeşi ilk müezzin oldu. ${ }^{77}$ Ezan da Kur'ân'da yapıldığ 1 gibi doğal bir terennüm olarak kabul edilir. Her ne kadar şarkı söyleme ve terennüm

gerçekten söylesem de söylemesem de O’na uygunsa ben söylemişimdir.” Bk. Goldziher, Muh. Stud., 48,

72 Lammens, Melanges de la Facultt Orientale (Beyrouth), iii, 230-3.

73 Hirschfeld, 37.

74 İkdül-ferid, iii, 178.

75 Profesör D. B. Macdonald, Seyyid Mürtezâ'nın İthalü’l sadâ’sından alıntı yaparak tâbir (ifade) yazıyor ancak İbn Haldun'da Quatremere'nin metninde ve Von Hammer'in çevirisinde tağbir olarak geçiyor. Krş. Dozy, Glossaire, i3 Ebu İshak ez-Zeccâc (ö.922) tağbir olarak kabul eder ve kelimenin ğabir'den türediğini ifade eder.

76 İbn Haldun, Mukaddime. Texte arabe publie par M. Quatremere., ii, 359

77 Buhari, i, 209 Mişkatü'l Mesâbih, i, 141

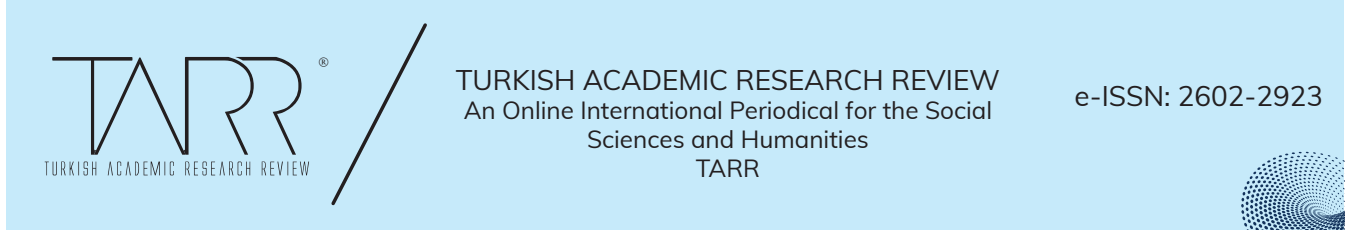


arasında meşru bir ayrım yapılsa da, İbn Kuteybe'nin (ö.889?) kesin ifadelerine bakılırsa; Kur'ân, sıradan sanatsal şarkılardan (Elhanü'l-ğınâ) ve kervan şarkılarından (hudâ) farklı hiçbir kuralla söylenmemektedir. ${ }^{78}$ Nitekim açıkça söylendi ki; eğer melodiler (Elhan) "haram" olarak düşünülseydi Kur'ân ve Ezan terennümleri de melodiyle eş tutulurdu ve bunu terk etmek daha iyi olurdu. ${ }^{79}$ Öyle ki Kur'ân'nn terennüm edilmesine Şafî̂ mezhebi tarafından izin verilmesine rağmen Mâlikî mezhebi tarafından yasaklanmıştır. ${ }^{80}$ Hanbelî haricindeki tüm mezhepler Ezan'ın terennümüne müsaade etmiştir.

Bu "helal” müzikal geleneklerin yanı sıra, Pagan Arabistan'da sosyal yaşama nüfuz eden, hareket halindeki diğer birçok Sami geleneği gibi İslam'ın da kısıtlamada muvaffak olamadığı gelenekler vardı. ${ }^{81}$ Hıristiyan Roma imparatorları gibi, toplumu dilediği gibi şekillendiremeyeceği anladığında, [Hz.] Muhammed de, kendisini toplumsal direnişe uyarlamak zorunda kaldı; bu nedenle, melahi veya "yasak zevklerine” rağmen Pagan festivalleri yeni yaptırımlar altında kabul edildi.

Bunların başında, İslam tarafından güzel görülerek uyarlanmış olan tehlil ve telbiye gibi eski Pagan hac ilahileri "meşrulaştırıldı" ve beraberlerinde şahin ve tabl gibi sazları çalmak bile "caiz" oldu. ${ }^{82}$ Hac için müzik bir gereklilik oldu. ${ }^{83}$

Savaş şarkısı başka bir deyişle kâfirlere karşı savaşmaya cesaretlendiren şarkı mübahtır çünkü: o, bir kimsede "inkârcılara karşı öfke ve gazabı körükler ve cesaretlendirerek savaşa teşvik eder." Recez ${ }^{84}$ vezniyle yazılan mevcut savaş şarkılarına da bu gerekçelerle izin verildi. Fakihler çoğu durumda önleyemeyecekleri şeylere izin verdi çünkü bu geleneklerin çoğu, Sami halklarında bir hüküm ile kaldırılamayacak kadar derin köklere sahipti. Bu [Hz.] Ali ve [Hz.] Halid'in ve [Hz.] Peygamber'in diğer cesur sahabîlerinin de gelenekleri olmuştu. ${ }^{85}$ Fakat şahin'in dokunaklı sesi "kalpleri yumuşatmasın" diye ordugâhta çalınması yasaklandı. ${ }^{86}$

Pagan karakterli olmalarına rağmen ağıt (nauh) [niyahat] veya mersiye, İslam için de yabana atılamayacak kadar önemli bir değer olduğundan caiz görüldü. (Belirli durumlar hariç) [ölünün arkasından yakılan] ${ }^{87}$ velveleli ağıt veya isyan görünümlü

78 İbn Kuteybe, 265

79 İkdü'l-ferid, iii, 178

80 İbn Haldun, ii,357 [“ỉleride ilimler bahsinde açıklanacağı gibi, seslerin (belli ölçülerde kulağa hoş gelecek şekilde) ahenkli olarak çıkartılması, musikinin ilgi alanına giren nağmedir (makamdır). İmam Malik Kur'an'ın bu şekilde okunmasını kabul etmemiştir. İmam Şafii ise buna cevaz vermiştir. Ancak Kur'an'ın makamlı okunmasından kasıt, musikide şarkı söyler gibi okumak değildir. Kur'an'ın bu şekilde okunmayacağı konusunda bir anlaşmazlık yoktur. Şarkı söylemek, Kur' an okumaktan her açıdan farklıdır.” İbn Haldun, M. ((Mukaddime, 2 cilt (H. Kendir, Çev.)•) İstanbul: Yeni Şafak Yayınları (2004)•] (Ç.N)

81 Ebu’u Fidâ diyor ki: İslam'ın kabul ettiği şeyler Cahiliye Araplarının yaptığı şeylerdi.

82 Gazzâlî, İhyâu 'Ulûmi'd-Din, s.220.

83 Gazzâlî, İhyâu 'Ulûmi'd-Din, s.221.

84 Aruz sisteminde bir bahir adıdır. (Ç.N)

85 Gazzâlî, İhyâu 'Ulûmi'd-Din, s.222.

86 Gazzâlî, İhyâu 'Ulûmi'd-Din, Bu sebepten dolayı, Haçlı seferlerinden birine dair olan Arapça günlüklerden birinde, Müslümanların ordugâhlarından flütleri çıkarmış oldukları yazılmıştır.

87 ["Kaybettiğinize üzülmeyesiniz...(Hadîd, 23)" Ölülere mahzun olmak da bu kabildendir. ] (Ç.N.) Bk. Gazâli, Ebû Hâmid Muhammed. "İhyâu 'Ulûmi'd-Din, çev." Ahmed Serdaroğlu (İstanbul: Bedir Yay., 1975) (1975).

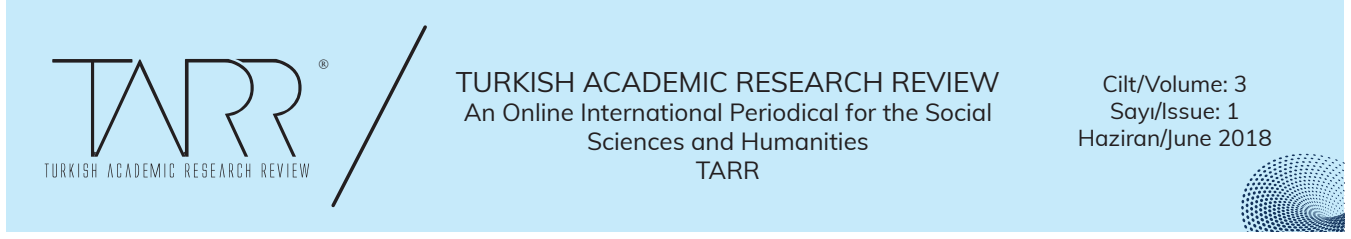


ağıt yasaklanmış olmasına rağmen yüzyıllar boyunca tüm cezalara karşın hala devem ediyor. ${ }^{88}$

O zamanlar Pagan Arabistan'da bol miktarda bayram ve şenlik müziği vardı. Bu da, İslamiyet ile gelen halk bayramlarında -günümüzde var olan Kurban Bayramı, Ramazan Bayramı, aşure günü ve çeşitli mevlidler olarak- yer buldu. ${ }^{89}$ Nişanlar, dügü̈nler, doğumlar ve sünnet merasimleri gibi özel şenlik günlerinde eğlenceye cevaz verildiği zamanlarda müziğe de cevaz verildi. Son olarak aşk şarkılarına da cevaz verildi.

Fakat fakihlerin bile hesaba katmadığı bir şey vardı ki o da müziğin ruhsal etkileriydi. Eskinin sihirbazlarına ve kâhinlerine insanlar üzerinde olağanüstü güç sağlatan şey de buydu Tuhaf gelse de fakihler bunu kavrayamadılar. Arap geleneğine göre [Hz.] Davud, kuşları ve hayvanları sesi ve kutsanmış boğazındaki yetmiş iki ton/nota vasıtasıyla dinlemeye çağırd1.${ }^{90}$ Sesini duyan insanlar kendinden geçerek öldü. ${ }^{91}$ Müziğin gizemli gücü, Arapların gündelik hayatlarında kendilerinin tecrübe edebileceği bir şeydi. Ritim veya ölçüdeki bir değişikliğe göre devenin adımlarını değiştirdiğini gördüler. ${ }^{92}$ Geyikler melodi ile uysallaştı ${ }^{93}$, yılanlar büyülendi, arılar yere kondu ${ }^{94}$, kuşlar müziğin sesinden bilfiil ölüverdiler. ${ }^{95}$ Güzel Ses'ten derinden etkilenen insanların olduğunu bize anlatan bol miktarda literatür var. ${ }^{96}$ Ancak, fakihlerin, sarhoşluğa ve zinaya teşvik ettiğini söylediği bu müzikle "ruhsal” müzik nasıl bir ilişkiye sahiptir? Bu soruya sufiler cevap verecek.

"Müzik ve şarkılar kalpte bulunmayan şeyleri üretmez." der Ebu Süleyman edDârânî(d.820). ${ }^{97}$ Böylece, Keşfü’l Mahcûb’un yazarı Hucvîrînin (11. yüzyıl) yaptığı gibi müzikten etkilenenler şu iki sınıfa ayrılabilir: (1) Ruhsal manayı duyanlar ve (2) Maddi sesi duyanlar. "Her iki durumda da iyi ve kötü sonuçları vardır."der yazar. Tatlı nağmeleri dinlemek, kişinin özünde bir coşkusunu üretir: eğer öz doğruysa doğru, eğer öz yanlışsa, yanlıştır." "İnsanın huyu esasında kötüyse duyacağı şey de kötü olacaktır." ${ }^{8}$ Sonra [Hz.] Muhammed'den alıntı yaparak devam eder: "Ey Allah'ım, bana eşyanın hakikatini göster." Bunun sonucunda yazarımız der ki: "İşitilen her şeyin iyi ya da kötü olduğu doğru duyum belirler". Bu nedenle sufiler müziği, vecd halinde elde edilen bir keşif aracı olarak gördü.

Zünnûn der ki: “Sema; Allah'ı anlamak için kalbi titreten ilahi bir etkidir. Musikiyi manen dinleyenler Allah'a ulaşırlar, onu bedenen dinleyenler ise sapkınlığa düşerler." Diğer bir sûfi İmam-1 Şibli der ki: "Müzik dinlemek zahiren baştan

88 Ali Bey, i, 183

89 Eid al-adha (Kurban Bayramı) Zilhicce'nin 10'unda kutlanılır ve bu gün, Pagan Arapların Minâ vadisinde kurban kestikleri önemli bir gündür.

90 Mirhavend, ii (I), 57.

91 İkdü'l-Ferid,iii, 179. Keşǘl Mahcûb

92 İkdü'l-Ferid,iii, 177. Gazzâlî, 219.

93 Keş̧ü'l-Mahcûb, 400.

94 İkdü'l-Ferid,iii, 177

95 Eğani, v, 52. Gazzâlî, İhyâu 'Ulûmi'd-Din s.219. Sadi, Gülistân, ii,27. iii.28

96 İkdü'l-Ferid, iii, 198. Gazzâlî,715. Keşfü'l Mahcûb, 407.

97 Gazzâlî, İhyâu 'Ulûmi'd-Din, s.220.

98 Keşfül'-Mahcûb, 402-3

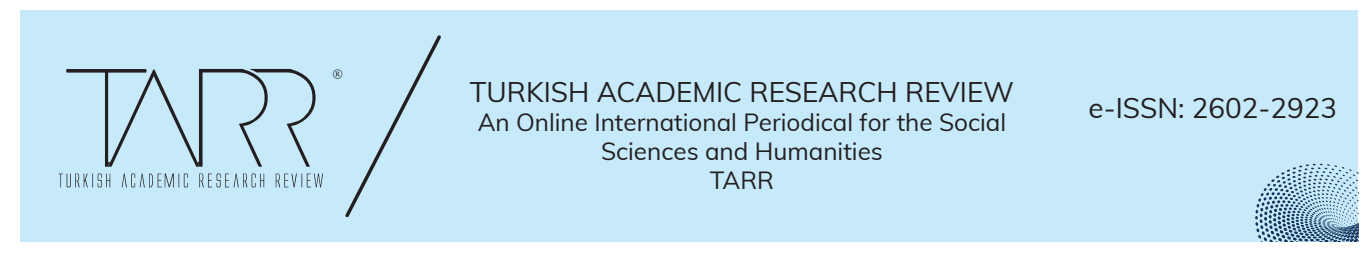


çıkarıcı, manen nasihat edicidir." Ebu Hüseyn el-Derrâc da "Dinlemek... perdenin arkasındaki Hakikatin varlığını bulmama sebep oluyor."der.

Sufilerdeki müzik düşüncesinde, Hucvîrî ve Gazzâlị̂99 örneğinde olduğu gibi modern dönemde Schopenhauer'un ileri sürdüğü çoğu şeyi görürüz. Sonuncusuna göre [Gazzâlî], müzik ebedi iradenin bizatihi kendisidir ve onun aracılığılyla bir kimse Perdeyi delebilir, Seyredeni müşahede eder ve Görünmeyeni görür. [Ayne’1 Yakîn- Hakka'l Yakîn]. ${ }^{100}$ Böylece müzik; bütün her şeye rağmen İslam'in yardımcısı olarak kültüre dahil edildi ve İslam'a [kısıtlamalara] rağmen tüm İslâm coğrafyasında da böyle kabul edildi.

\section{II}

[Hz.] Muhammed ile çağdaş olan müzisyenlerin birçoğundan önceki bölümde bahsedildi. Bunların dışında [Hz.] Peygamber ve İslam ile şahsi ilişki kuran az sayıda kişi vardı, ki bunlardan bu bölümde bahsedeceğiz.

Bilâl b. Rebâh Habeşi (v.641), [Hz.] Ebubekir tarafından fidyesi ödenmiş olan Habeşistan kökenli bir cariyenin oğluydu. O, İslam'ı kabul eden ve bu yüzden eziyet edilen ilk kişilerden biriydi. [Hz.] Muhammed onu "Habeşistan'ın İlk Semeresi” olarak isimlendirmiş ve onu emanetçisi yapmıștır. [Hz.] Peygamberin kendisine: "Ey Bilal, bize bir gazel oku" dediği söylenir. O, İslam'ın ilk müezziniydi ve günümüzde müezzinlerin piri olarak kabul edildi. Bilal, mezarının görülebileceği Şam'da vefat etti. ${ }^{101}$

Şîrîn [shîrîn], [Hz.] Peygamberin şairi Hasan b. Sâbit'in cariyesinin ismidir. ${ }^{102}$ Mısırlı kız kardeşi Mâriya'yla, 630'da Mısır valisi Mukavkıs tarafından [Hz.] Peygamber'e gönderilen köle kız Sîrîn [Sîrîn] olduğu ihtimal dışı değildir. Mâriya [Hz.] Peygamberin eşlerinden biri olurken, Sîrîn Hasan b. Sabit'e hediye edildi. ${ }^{103}$ "Hulefâ-i Raşidin” döneminde, ünlü kadın şarkıcı Azza İzzetü’l Meylâ’nın -Hasan b. Sabit'in cariyesi Şîrîn veya Sîrîn ile aynı kişi olması muhtemel- erken dönem kaynelerinden Sîrîn adında bir kaynenin şarkılarını söylediğini bilmekteyiz. ${ }^{104}$

Diğer üç kaynenin isimleri, [Hz.] Peygamber'in bir fatih olarak miladi 630'da Mekke'ye girmesinin hemen öncesinde, [Hz.] Peygamber tarafından idam edilmek üzere mahkûm edilmelerinin sonucunda ulaşmıştır. Onların suçu, [Hz.] Peygamber'e karşı hiciv şarkılarını söylemiş olmalarıydı. Bu şarkıcı kızların ilki; Amr b. Hişâm (ya da Haşim) b. Abd'ül- Muttalib (Ebû Cehil)'e ait olan Sâra'ydı. O, "yerinde bir itaatle"105 ölüm cezasından kurtuldu. ${ }^{106}$ Abdullah (Hilâl) b. Hatal

99 Hem Gazzâlî̉nin İhyâü Ulumi-d Din'nindeki müzik bölümü ve hem de Hucvîrînin Keșfü'l Mahcûb’u İngilizceye tercüme edilmiştir. Bk. Bibliyografya

100 Gazzâlî, İhyâu 'Ulûmi'd-Din, s.720.

101 İbn Hişâm, 205. Caetani, iii, 99. Evliya Çelebi, i, (ii), 91, iii. Nevevî, 176.

102 Keşü’l-Mahcûb, 411

103 Teberî, krş. İndeks.

104 Eğani, iv, i4. Guidi, onları birbirinden ayrı iki kiși olarak kabul eder.

105 [Fidyesinin ödenmesi şeklinde yorumlanabilir.] (Ç.N).

106 Muir, Mohammad, 411.

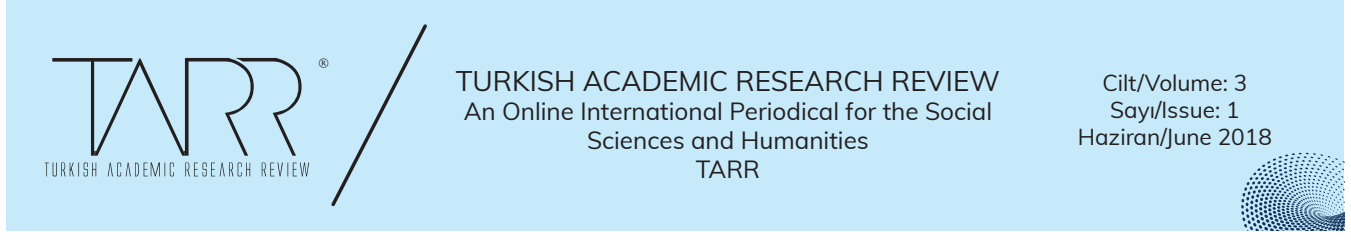


Hadramî’nin hizmetindeki Kurain (Kureynâ veya Fertanâ) ve Kuriba (Ernab) da cezalandırıldı. Yalnızca Kurain ölüm cezasına çarptırıldı. ${ }^{107}$

Nispeten modern bir Türk otoritesi olan Evliya Çelebi'den (ö.1680?), [Hz.] Peygamber’in önünde müzik icra eden üç erkek müzisyenin ismini öğreniyoruz. $\mathrm{Bu}$ isimlerinden yalnızca bir tanesi klasik kaynaklarda ispatlanabilir, onun müzikal başarılarından son kaynakta [Seyahatname] hiç zikredilmese de bu kişi Amr b. Ümeyye'dir. ${ }^{108} \mathrm{Bu}$ kişilerin ikisi müzik cemiyetlerinin piri olarak iddia edildiğine göre, bu rivayetin kökeninin erken döneme dayandırılamaması şaşırtıcıdır. Evliya Çelebi'nin zikrettiği üç müzisyen:

Amr b. Ümeyye Z[D]amîrî, ayrıca Baba Ömer veya Amr-1 Ayyâr olarak da bilinir, [Hz.] Ali ve [Hz.] Fatıma’nın düğününde daire (def) çaldığı söylenir ve tüm daire çalanlar onu daire çalanların piri olarak görür. ${ }^{109} \mathrm{O}$, “[Hz.] Peygamber'in ashabindandı".

Hamza b. Yetîm'in Bilal-i Habeşi ile [Hz.] Peygamberin huzurunda şarkı okuduğu ve [Hz.] Ali (veya Selman el-Farisi) tarafından giydirildiği söylenir. Onun ayrıca [Hz.] Ali ve [Hz.] Fatıma'nın düğününde de şarkı okuduğu söylenir. Bütün şarkıcıların piri olduğu ve mezarının Tâif'te olduğu ifade edilir. ${ }^{110}$

Baba Sevindik, [Hz.] Peygamber'in askeri seferlerinde kös [kös ve nakkare] olarak adlandırılan bir davulu çaldığı söylenen bir Hintliydi. Kabri'nin Musul'da Çercîs yakınlarında olduğu söylenir. ${ }^{111}$ 